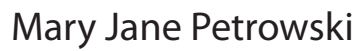 \\ ACRL membership benefits you Increase your effectiveness, value, and connection to the profession
}

C harting Our Future: ACRL Strategic Plan 2020," challenges ACRL to position academic and research libraries and librarians as indispensable to advancing learning and scholarship.

Over the past few years, we've interviewed our members to discover why they join (and continue to belong). See the ACRL "Meet Our Members" page (www.ala.org /ala/acrl/aboutacrl/acrlmembership /acrlmembers.cfm) to read more personal statements about the benefits ACRL members value.

\section{Communities of success}

ACRL is home and family for more than 13,000 academic and research librarians. It's large enough to provide resources to help with any issue, but also small enough for members to get to know a core group of colleagues with similar interests and passions.

New librarians can connect with other librarians and the profession; rural, community college, and non-faculty librarians value the connection that ACRL provides to those in more isolated environments: "I developed several close friendships with other librarians who have continued to help me learn and explore as new technologies were introduced. We learn so much by sharing our experiences with each other and helping each other stay abreast of new developments in our rapidly changing environment."

ACRL members gain an "essential national connection" that allows them to identify themselves, find other deep engaged professionals, and form mutually beneficial communities. The sharing of experience and ex- pertise among members creates an inclusive, vital, and supportive channel that facilitates networking and collaboration.

ACRL brings members into the wider community of academic librarianship through communities of practice, discussion lists, national conferences, and publications.

\section{Specialized resources}

ACRL keeps members informed regarding the issues facing academic libraries and the profession through information sharing on discussion lists, blogs, wikis, podcasts, open e-forums, and publications.

ACRL provides members with up-to-date information, guidelines, standards, research, and statistics to help academic and research librarians analyze trends and make informed decisions for managing information services.

ACRL helps members become better acquainted with effective practices throughout the profession. As one member noted, "ACRL offered those of us who were new to librarianship a wide variety of resources on which to lean as we made our way in this demanding profession."

Advancement: Advancement involves research, publication, and presentation. Bottom line: the growth opportunities provided by ACRL can advance your career. ACRL publications, including CERL News, CERL, and Choice, allow members to keep up with (and influence) the field. ACRL strives to help

Mary Jane Petrowski is ACRL associate director, e-mail: mpetrowksi@ala.org

c 2008 Mary Jane Petrowski 


\section{Members tell why they joined ACRL}

“My reason for joining ACRL has stayed my reason for continuing to be a member of ACRL: opportunity. The opportunity to work on projects that build my professional skill set. The opportunity to stay not only informed about, but involved in, emerging professional trends. And the opportunity to meet and work with my professional heroes and make new heroes that inspire, teach, and provoke me into thinking in new and deeper ways.-Randy Hensley, Student Learning Programs and Services, University of Hawaii-Manoa

"I joined ACRL as much to show my support for the organization as to gain support from the organization. ACRL is clearly an organization of deep-thinking, committed people who understand the issues that are unique to academic libraries."-Beth Evans, Brooklyn College Library of the City University of New York

“Programs offered by ACRL have not only contributed to my own professional development, they have also helped me with mentoring younger professionals who are becoming leaders in my library.-Teresa (Terri) Fishel, library director, Macalester College

"I knew almost immediately in graduate school that I wanted to be a part of an association that fosters collegiality and communication among academic librarians. ACRL is definitely that group! Since joining, I've gained insights into this profession that I can always carry with me."-Melissa Mallon, library instruction coordinator/reference librarian, University of Pittsburgh-Johnstown

"I joined because I knew it to be a first-rate professional association for academic librarians, one that would help me advance in my career-and it has." - Todd Gilman, Librarian for Literature in English, Yale University members achieve their greatest potential as academic librarians. Through professional development programs, conferences, publications, virtual workshops, discussion lists, and committee participation opportunities, ACRL provides a supportive infrastructure for each member to achieve a high level of personal continuous learning while building a network of supportive colleagues.

In the words of one member, "ACRL is my most valued tool for professional development."

Institutional Enhancement: The academic/research community benefits from the ongoing growth and development of our members and represents the ultimate return on your membership investment.

ACRL is dedicated to developing members who are recognized as flexible, dynamic, and entrepreneurial leaders in their institutions and in scholarly communities. Members recognize that their self-development ultimately benefits their institution: "ACRL membership is not just for you but for your library."

Professional Pride: ACRL membership demonstrates solidarity and support for the profession as well as the work of ACRL in developing standards and guidelines for the profession. ACRL provides an opportunity for members to leverage their creativity, talent, and experience on behalf of higher education.

ACRL members take pride in shaping the future of the association and giving back to the profession. As a member, you support the voice of academic and research librarians in higher education as well as in the library community.

\section{Join today}

ACRL can increase your effectiveness, value, and connection to the profession. Membership application forms are available online at www.acrl.org.

Become our newest member today and let ACRL help you connect, contribute, and stay current. $z$ 